\title{
Institutions as Constraints and Enablers: Changes in Human Resource Management Practices of Foreign Companies during Economic Reform in China
}

WEI LU

\begin{abstract}
This article demonstrates how the development of labour market institutions alongside economic reform has impacted the human resource management (HRM) practices of foreign companies in China. A historical approach is applied to examine the transformation of China from a centrally planned labour administration system to a market-based labour institution. The HRM practices of foreign companies are seen being embedded in China's macro-institutional environment, which constrains and/or enables foreign companies to exercise people management. Drawing on previous research, the study shows that HRM practices in the early reform period were primarily constrained both by formal and by informal institutions. The evidence from Finnish companies operating in China shows that HRM practices in the late reform period are largely enabled by formal institutions; however, foreign companies face the need for adaptation to the demands of informal institutions. Furthermore, the scarcity of human resources and rapid yet heterogeneous socio-economic development pose additional challenges for people management in China today.
\end{abstract}

Keywords: economic reform, institutional transition, labour market institution, human resource management (HRM) practice, foreign companies, China

\section{Introduction}

December 2018 marks the 40th year of China's economic reform. Over the past four decades, China has been transformed from a socialist planned economy to a socialist market economy. ${ }^{1}$ China has experienced its fastest economic development since economic reform and its opening up to the outside world in 1978. Foreign direct investment (FDI) has been a key driver of this growth. China ranks as the world's 
second largest country in terms of both FDI inflow and attractiveness to multinational companies (UNCTAD 2018). Foreign invested enterprises already account for 45 per cent of China's exports and imports and generate 25 per cent of total industrial profits (Report on Foreign Investment in China 2018).

Much research has been conducted into the transformation of China's economic system and the subsequent outcomes, such as growth dynamics and economic organization (see Brødsgaard and Rutten 2017). Yet few studies have taken a longitudinal approach to examine how the institutional transition has influenced human resource management (HRM) practices of multinational corporations (MNCs) over time in China. Although some earlier studies have highlighted some changes in HRM (e.g. Björkman et al. 2008), these studies typically lack the perspective of macro-institutional transition. The present study examines the changes in HRM practices of foreign companies in China in the context of the macro-institutional transition from the early reform period to the late reform period, with an emphasis on labour market institutions and their subsequent impact on HRM practices, providing a comparison of HRM practices between these two periods.

The notion of formal and informal institutions (North 1990) serves as a broad theoretical framework with which to examine the macro-institutions in China during the economic transition. According to North (1990: 3 ), institutions are the rules of games in a society or, more formally, the human-devised constraints that shape human actions. Formal institution refers to political and juridical rules, economic rules and contracts, while informal institution refers to conventions and codes of behaviour where culture is incorporated (North 1990). Hierarchically, formal rules range from constitutions to statute and common laws to specific by-laws and finally to individual contracts (North 1990: 47). These formal and informal rules define what individuals are prohibited from doing and under what conditions they are permitted to undertake certain activities. Therefore, formal and informal institutions act as a framework within which human interactions take place. A major role of institutions is to reduce uncertainty and thus provide stability for human interactions. Furthermore, in the absence of formal rules, informal rules can play a greater role in coordinating human interactions. For example, personal relationships among managers in China served as informal substitutes for formal institutional support, allowing enterprises to grow in the absence of market economy institutions (Peng and Heath 1996).

Prior to economic reform, China was a typical centrally planned 
economy. A fundamental feature of such a system is that economic transactions are undertaken and coordination among economic players is achieved by means of bureaucratic control. The central planning bureaucracy as a formal institution plays many key roles in the establishment and liquidation of firms, management of production, allocation of products and materials, decisions on pricing, investment, technology and foreign trade, appointment, promotion and dismissal of managers, and allocation and management of labour (Peng 2000). For instance, workers were assigned and paid according to centralized reward scheme determined by the labour administration organ. Workers were entitled to lifetime employment, and managers had little discretion to discipline workers (Tung 1982; Walder 1989). The economic reform has gradually transformed such a central labour management system to the current market based labour system. Foreign enterprises are seen being embedded in the macro-institutional environment that constrain and/or enable them to exercise desired people management practices.

The structure of this article is organized as follows: after the introduction, the context of China's economic reform is presented. It continues with a discussion about the evolution of labour market institutions, followed by the institutional environment and HRM practices in the early reform period and then the later reform period. The article concludes by highlighting the changes in HRM practices at foreign MNCs between the two periods of economic reform.

The analysis of HRM practices in the early reform period is based on published empirical studies, whereas that of the later reform period is based on the interviews undertaken for two research projects that took place between 2005 and 2011 (Kettunen et al. 2008; Lu 2014). ${ }^{2}$

\section{The Context: Macro-Institutional Transition in China}

Economic reform in China has been typically described as having the Chinese characteristics of pragmatism, gradualism, experimentalism and incrementalism. Deng Xiaoping, the advocator and pioneer of the reform, vividly described this with a famous slogan about a black cat and a white cat: 'It does not matter if it is a black cat or a white cat. It is a good cat if it can catch the mouse.'

Economic reform officially commenced with the Third Plenary Session of the Eleventh Central Committee of the Communist Party of China (CPC) in 1978. Unlike Eastern and Central Europe and the former Soviet Union, which initially launched a rapid and massive privatiza- 
tion programme of state enterprises, economic reform in China started in the agricultural sector. The 'household contractual responsibility system' (jiating lianchan chengbaozhi) was initiated in rural areas in 1978 and soon spread all over the country (Chai 1998). By the end of 1984, 93 per cent of China's cultivated land had been contracted to households, and 100 per cent of rural villages had chosen to fix production quotas on a household basis (Chen 1995: 23). The People's Communes, a collective mode of agricultural production, were replaced by individual household farming. This new system greatly motivated the peasants to produce more crops and other agricultural produce. This phase was termed by the Chinese government as 'socialist planned economy with assistance of market force'.

The reform shifted to the industrial sector in 1984 (Chai 1998) when two important policies were introduced. In May 1984 the State Council promulgated the 'Provisional Regulations on Further Expanding the Autonomy of the State-Owned Industrial Enterprises' (State Council 1984); and in the same year the Third Plenary Session of the Twelfth Central Committee of the CPC passed the Decision on Economic Reform that stated that a socialist economy is a planned commodity economy based on public ownership (CPC 1984). This latter is the first official recognition of a commodity economy and indicated the Communist Party's desire to gradually dismantle the central planning system. Early industrial reform focused on expanding the autonomy and restoration of financial incentives of state-owned enterprises (SOEs). The former means decentralizing economic activities while the latter means profit retention. Procurement of materials under planning allocation was reduced. Enterprises began to purchase part of their raw materials via market channels. Investment decisions began to decentralize to local governments and further down to the enterprises. Financing sources were also enlarged to loans from banks and investment by domestic and foreign enterprises (Chai 1998).

One key form of the industrial reform that took place was the 'enterprise contractual responsibility system' (qiye chengbao jingying zerenzhi), which was borrowed from the successful household responsibility system used in agricultural reform and introduced to SOEs in 1987 (OECD 2005). The other was leasing out small and medium-sized SOEs. The objective of SOE reform was to separate the ownership right and operations right to an appropriate degree; in other words, the enterprises were still owned by the state but were operated by managers. A third important issue was the separation of state administration from the 
operation of enterprises. With these measures, enterprises started to bear responsibility for their profits and losses. In 1986 the Provisional Law on Bankruptcy was passed for SOEs (NPC 1986). This was the first enterprise law concerning SOEs since 1949. Under it, SOEs were officially recognized as economic entities that take responsibility for their own operation and economic results. This period also experienced the emergence and rapid growth of the private sector. During 1984-91, the growth in industrial output was highest in private enterprises (45 per cent) and foreign invested enterprises (47 per cent), and lowest in SOEs (only 8 per cent) (China net 3 April 2003). A number of laws relating to self-proprietorship (getihu) and private enterprises were introduced as well, signalling further development toward a market economy.

The Fourteenth CPC Congress in 1992 marked a new era of economic reform. The Congress decided that the goal of economic reform was to establish a 'socialist market economy' (shehui zhuyi shichang jingji) and that all enterprises should enter into and compete in the market. With this, the concept of market economy was officially recognized for the first time. The Third Plenary Session of the Fourteenth CPC in 1993 set out the transformation of the operational system and establishment of a modern enterprise system as the targets of SOE reform. In 1993 the first Company Law was introduced (NPC 1993). This came to govern all types of enterprises, indicating a shift to the market coordination of economic activities in all sectors. The Fifteenth Congress, in 1997, called for acceleration of the marketization (shichanghua) of the national economy as an important target. Market mechanisms were increasingly applied in many economic activities, for example the commodity market and the capital market. At enterprise level, this marked the beginning of a massive restructuring of SOEs. Their marketization meant restructuring enterprise ownership, transforming SOEs into stock companies, establishing a market operation mechanism within SOEs and inducing them to compete in the market. The goal was to retain the large SOEs and let go of the small and medium-sized ones. Most SOEs lost their support, subsidies or free loans from the government and began to strive for profitability in order to survive in the market. As a result, a huge number of small and medium-sized SOEs were merged, restructured, acquired or allowed to go bankrupt (Yusuf et al. 2006).

The later reform of SOEs focused on their transformation into stock companies, which took place from the early 1990s and throughout the 2000s (People net 10 Janaury 2009). The experiment with 100 large SOEs began in the mid-1990s (China net 3 April 2003). State ownership was 
transformed into tradable stock. Governments at central, provincial and municipal levels became owners of stock in SOEs. Some stock companies were later listed on the stock exchanges in Shenzhen and Shanghai. The Third Plenary Session of the Fifteenth CPC Congress in 1998 further defined China's economic system as being mainly based on public ownership but with the coexistence of multi-ownerships.

Private ownership in enterprises was officially accepted as part of the national economy in 1988. The Constitution Amendment in 1999 explicitly recognized private ownership for the first time since 1949 (NPC 1999). The 2004 Constitution was amended to further guarantee the right to own private property (NPC 2004). This series of official recognitions of private ownership and private property were important steps and landmarks in the development towards a market economy.

\section{Emergence and Establishment of Labour Market Institution}

The pre-reform labour system was characterized by the so-called three irons: iron bowl (tiefanwan, lifetime employment), iron wage (tiegongzi, fixed wage) and iron chair (tiejiaoyi, permanent position). Labour was assigned according to quotas that were defined and allocated by the administration authority of the enterprise. In other words, the enterprise had to obtain a labour quota (zhaogong zhibiao) if it wanted to hire people. Cadres (ganbu) could keep their positions as long as they followed the Communist Party line. There was also a rule called replacement (dingti), which meant children were entitled to replace their parents when the parents retired. Furthermore, there was strict control over the mobility of the population, especially from rural to urban areas. This control was administrated by the hukou (residence registry) system that tied individuals to their place of birth. This centralized labour system was part of the central planning regime.

In the mid-1980s, when economic reform shifted from agriculture to industry, economic activities were increasingly conducted based on a market mechanism. These changes required a market-supportive labour system. Enterprises were granted some freedom in hiring and firing thanks to the above-mentioned central government policy entitled 'Provisional Regulations on Further Expanding the Autonomy of StateOwned Industrial Enterprises' of 1984, which covered in ten operational areas: production planning, product sales, product pricing, material purchasing and labour issues (e.g. defining wage level) among others 
(State Council 1984). Since 1985, the labour quotas for most large and medium-sized SOEs were no longer fixed but were allowed to fluctuate according to the production output volume (Chai 1998). For small enterprises under a contractual or leasing system, labour quotas were completely abolished. Enterprises started to experience a degree of freedom in hiring and firing. Nevertheless, this right remained largely theoretical in the 1980s, because it was difficult to enforce in state enterprises (Chai 1998). As a result, the free movement of labour, which is the prerequisite of a labour market, was much constrained. One key factor behind this was that SOEs continued to play the role of danwei (or work unit), a mini welfare state. ${ }^{3}$ Workers still relied on their work unit to provide housing, medical care, children's schooling and other social services. Another reason was that the state still controlled a considerable part of the labour supply. Even in 1992, one-third of the new employment in SOEs was assigned by the government, with two-thirds being recruited by the enterprises themselves (Chen 1995). A third reason was that the hukou system prevented people from moving between cities and regions, especially from rural to urban areas and from smaller towns to larger cities.

It was the deep reform of SOEs from the late 1980s to the early 1990s that eventually triggered the emergence of a labour market in China. SOEs were undergoing massive restructuring. Under the pressure of survival in the market, they began to seek efficiency. Not only did they have to reduce their workforces, but they also had to shut down unprofitable enterprises. ${ }^{4}$ The quota for recruiting staff in state enterprises was eventually abolished in the mid-1990s, and thereafter SOEs could freely hire workers (Knight and Song 2005).

The introduction of a labour contract system was an important step in transforming the centrally planned labour system into a labour market institution. As early as 1986 a labour contract was introduced to SOEs for the hire of new workers with the State Council 'Provisional Regulations on the Use of Labour Contract in State Owned Enterprises' (State Council 1986). However, this implied that a labour contract was applied only to a small number of workers because the majority of workers were already employed. Yung and Hong (2008) show that only 6 per cent of the employees in Shenzhen, one of the most developed areas in terms of reform, had a labour contract in 1990. In 1992 the contract employment policy was extended to all employees in SOEs (Goodall and Warner 1997).

The Labour Law that was promulgated in 1994 and enacted in 1995 
legally defined the right of enterprises to hire and fire at national level (NPC 1994). The law unified various regulations and decrees that had applied to enterprises with different ownership structures and referred to different labour issues. Labour contracts became a legal requirement for all companies. The Labour Law was the first labour legislation at national level that embraced comprehensive issues on employment (Warner 1995). It can be regarded as the landmark for the establishment of a labour market institution in China, because it established an official system that aimed to safeguard, via a market-based mechanism, the free mobility of the labour force and enterprise autonomy in decisions relating to labour on the one hand, and to protect the interests of workers and employers on the other hand.

\section{The Institutional Environment for Foreign Companies during the Early Reform Period}

While Chinese SOEs were still operating under the regime of state allocation of labour resources, lifetime employment and a centrally controlled wage system, foreign enterprises were introduced to regulations that had some market economy features as early as 1980. The 'Provisions on Labour Management in Chinese-Foreign Equity Joint Ventures' that was promulgated in 1980 by the State Council was the first state regulation on labour management for foreign enterprises (State Council 1980). The Provisions permitted joint ventures (JVs) to manage their employees in recruiting, dismissal, remuneration, labour protection and labour insurance through a labour contract. However, the Provisions also set out a number of restrictions in hiring, firing and setting wages. For example, the labour contract in JVs had to be approved by provincial governments; JVs were to recruit employees recommended by the Chinese partner's administration organization, a government bureau; recruiting from other channels had to be approved by the labour authority; the JV's wage was to be set at 120 to 150 per cent of the SOEs in the same sector of the region/area; and dismissal for breaking company rules with an economic consequence had to be approved by the industrial bureau and labour authority. Furthermore, the chairman of the board of directors, the highest decision-making authority in a JV, had to be a Chinese person from its Chinese partner.

Along with the relaxation of policy on foreign investment, the regulations on labour issues for foreign companies were relaxed in the late 1980s. Many of the restrictions mentioned above were removed. One 
important decree was a circular issued by the General Office of the State Council in 1988 regarding the approval and transmission of proposals submitted by the Ministry of Labour and Ministry of Personnel concerning further implementation of the policy that granted decision-making powers to enterprises with foreign investment (State Council 1988). These regulations allowed foreign enterprises to recruit directly from other channels than those provided by the government and from other regions than the one in which the company was located, conclude a labour contract without approval by the government bureau and dismiss employees based on the terms of the labour contract. However, the relaxation was not linear and some restrictions were restored later, for example regarding the setting of wage levels (Greene 1991; Zhu and Dowling 2000).

This period was characterized by a dual track for labour regulations in two senses. First, there were different regulations for Chinese SOEs and foreign companies: the former were under the rules of the central planning labour system while the latter were under the regulations relating to the labour market system, as discussed above. Secondly, foreign companies operated under the regulations of both systems.

\section{HRM Practices of Foreign Companies during the Early Reform Period}

\section{Staffing}

With the restrictions in the early 1980s, as discussed, the main source of employees for Chinese-foreign JVs was the Chinese partner. JV was the dominant mode of FDI in the early reform period because there were many restrictions by the Chinese government relating to the establishment of a wholly foreign owned company. The Chinese partner therefore became the natural source of labour. Many SOEs had an excessive number of workers, and some were often transferred to the JV when it was established. Therefore, this inherited problem of over-staffing was partially imposed on the JVs (Verburg 1996). Because the major source of labour was internal transfer from the Chinese partner, there was little open recruitment. Furthermore, the regulations restricted external recruitment to the local area. Foreign invested companies could hire workers by visiting the local job centre and labour market events organized by the local labour authority. The managers of JV were recommended 
by the Chinese partner or their upper administrative organization, often a Communist Party organization. The personnel manager in JVs had to be a Chinese person (Verburg 1996).

At the end of the 1980s, foreign companies were able to hire people from outside their location city. Externally hiring employees who were not employed by the JV Chinese partner also gained wider acceptance (Greene 1991). However, recruiting a person who was fully employed by a SOE was difficult in practice (Child 1994). One obstacle was the hukou system; the other was the personnel file (renshi dangan) system. Under the central planning regime, a person's personnel file was kept by his/her danwei (work unit). Access to one's own personnel file was forbidden. If an employee changed work unit, the personnel file had to be transferred from the old work unit to the new one unit via inter-work unit transfer. Without the personnel file, the recipient work unit was not allowed to take in the new employee. Holding on to the personnel file was a common means in SOEs for preventing employees from changing their job. Even if a foreign company could find a suitable candidate, it might not be able to complete the recruitment process because of this problem (Tsang 1994), and it was a problem that was reported to varying degrees by foreign companies. Apparently it was not easy to recruit someone from a large SOE or state organization, because it was feared that SOEs would lose their best people to foreign enterprises. Often, recruiting foreign companies had to resort to help from the labour bureau to allow the potential candidate to be released from his/her Chinese work unit, and had to pay compensation for this to happen (Greene 1991). The transfer procedure was made even more complicated if recruitment was taking place across cities or localities. As many as 20 approvals could be involved, from, for example, the labour bureau, the public security bureau, other civil authorities controlling residence registration and even the recruit's spouse's work unit (Tsang 1994). This system prevailed until the 1990s. Today, the role of the personnel file is much less important: foreign and private Chinese companies usually do not require one, although the opposite is true for SOEs and government organizations.

The firing of unsatisfactory workers was troublesome as well. For instance, in an investigation of $30 \mathrm{JVs}$ in 1989, 29 of them encountered difficulties owing to Chinese managers' protection of their employees (Child 1994). This may reflect the deeply rooted thinking about life-time employment. The entire social system was still that of a central planning regime, meaning that enterprises were responsible for employee 
welfare. In the absence of social security, such as unemployment insurance, being unemployed meant losing one's basic income and therefore one's livelihood. Therefore, it was not only the mental barrier but also the system barrier that prevented firing and laying off. It was reported that one way to get rid of excess workers transferred from the Chinese partner of the JV was early retirement (Verburg 1996). Towards the end of the 1980s firing employees became less difficult, and some foreign companies were able to lay off so-called unproductive workers.

\section{Reward}

Wages tended to be defined in foreign companies with minimum gaps between employees. Large gaps in wages were avoided. There was internal resistance in JVs, as well as external pressures, against introducing individualized incentives that would reflect job performance and responsibility levels (Child 1994; Greene 1991). Although the regulations on minimum and maximum wage limits for JV employees were abolished at the end of the 1980s, external influence from labour authorities still existed until the early 1990s. Greene (1991) reports that a majority of the foreign invested enterprises interviewed in 1990 by the US-China Business Council indicated that they were pressed to control wage levels.

Although foreign companies were allowed to use an incentive scheme to reward employees whose work was outstanding, bonuses tended to be distributed equally to all workers and managers and often became part of the basic pay (Laaksonen 1988; Nelson and Reeder 1985; Zhu and Dowling 2000). This reflected the strong influence of the egalitarian legacy of the central planning regime. In a study of ten foreign-Chinese JVs Verburg (1996) finds that most of them used standard bonuses, such as national holiday bonus, profit-sharing and overtime pay; performance-related pay was applied only marginally in these JVs. Furthermore, production targets were often set and measured at group or company level. Chinese managers were assessed by the Communist Party and labour unions on their political conduct (Child 1994). Chinese managers and staff were sometimes rewarded by being offered training in the home country of foreign partners (Verburg 1996).

Apart from reward in the form of wages and bonuses, another typical material reward was subsidies. As Chinese enterprises still bore responsibility for their employees' social welfare, such as housing, medical care, daycare and schools, many JVs found that their ability to offer attractive housing subsidy is crucial to hiring and retaining good employees (Tsang 1994). 


\section{Institutional Environment for Foreign Companies in the Later Reform Period}

FDI experienced a boom when the policies relating to it were considerably relaxed after Deng Xiaoping's South China Tour in 1992. Foreign companies enjoyed preferential policies regarding taxation and import tariff, and land and labour use were prioritised for them. Wholly owned foreign companies were permitted and gained increasing popularity.

The labour reform reached a historical turning point in the 1990s. The Labour Law of 1995 officially marked the transition of the centrally controlled labour system towards a free market labour institution (NPC 1994). The law stipulated the labour contract as the means for establishing an employment relationship between worker and company. The lifetime employment system, the 'iron bowl', was officially abolished. The change from lifetime employment to fixed period employment has greatly facilitated labour movement. The short-term labour contract has become the prevailing employment relationship, especially in private and foreign sectors. Labour mobility across cities and regions, especially from rural to urban areas, has been rapidly growing since the 2000s when the restrictive role of hukou dramatically decreased.

Since the enactment of the Labour Law of 1995, the Chinese labour system has undergone rapid liberalization. This has greatly facilitated the development of a free labour market but has also largely failed to protect workers' interests and rights (Gallagher 2004; Wu 2006). This latter is primarily because there has been a lack of enforcement of employers' obligations to employees, especially thanks to extremely weak surveillance by local governments, who were faced with the need to attract and retain investment and grow local economies (Gallagher 2004). Economic development has been the priority for both central government and local governments since the reforms of 1978 . The promotion criteria of local officials have been measured by regional economic growth. They have lacked any incentive to vigorously oversee enterprises' compliance with the obligations required by labour regulations. Furthermore, corruption on the part of local authorities has also contributed to a lack of enforcement. According to a survey of China's National People's Congress in 2005, less than 20 per cent of the small and medium-sized enterprises used labour contracts ( $\mathrm{Wu} 2006$ ), though this was a legal requirement under the Labour Law of 1995.

The number of labour disputes was reported to be ten times greater in 2005 than it had been in 1995, and 94 per cent of cases were filed by em- 
ployees (Wu 2006). The media frequently reported that employers had failed to make wage payments, paid wages below minimum standards, evaded social insurance contributions, neglected safety at work, failed to make adequate compensation for overtime work or treated workers badly. Many disputes erupted into public demonstrations, even riots. Against this background, the Labour Contract Law of China was promulgated in 2007 and came into effect on 1 January 2008 (NPC 2007).

The core of the Labour Contract Law is to enhance employee protection by stricter rules for employer obligations and tighter surveillance. In fact, the changes between the Labour Law of 1995 and the Labour Contract Law are not that significant. Important differences are mainly the tightened surveillance and monitoring rules and the forceful campaign for worker protection by central government, with massive inspection actions being taken by authorities at various levels when the law was launched. The major impacts for foreign companies were identified in tightened employment contract terms and legislation relating to dismissals and employee representation ( $\mathrm{Lu} 2009)$.

Alongside these institutional changes, China has been experiencing fast economic growth for over two decades since the 1990s, with an annual gross national product growth rate of around 10 per cent. The 2000s reflected a new economic boom until the 2008 world financial crisis. This continuous fast economic growth resulted in a shortage of professionals and specialists, competent managers and skilled workers. Most case companies (see Note 2) reported challenges in finding suitable employees. As one company representative stated, 'It is very difficult to recruit people. In recent years there has been overheating in this sector. Qualified professionals were very few' (Interview with a Finnish general manager in China, 22 September 2008).

The increasing lack of skills intensified the fierce competition for talent. The tight labour market further accelerated the inter-firm mobility of those employees who were in high demand, namely specialists, experienced professionals and managers, because there were many opportunities in the labour market for them. 


\section{HRM Practices of Foreign Companies during the Later Reform Period}

\section{Recruitment}

The early established Finnish companies in China in the mid- to late 1990s were mostly JVs. Theoretically JVs did not have to recruit staff by taking in employees from the Chinese partner owing to the relaxation of relevant laws. Nonetheless, some Finnish companies regarded it as a quick and easy way to obtain workforce, and in addition Chinese employees from the Chinese partner often had a good relationship with the local customers and authorities. For instance, one Finnish - Chinese JV recruited all its workers and staff (about 600) from the Chinese partner and only the general manager, finance manager, technology manager and designer came from the Finnish side. However, a few other cases were reported as an 'arranged marriage', where the Chinese partner was recommended by the Chinese authority. In this situation the transfer of Chinese employees was often part of the JV agreement that the Finnish partner had to accept. There was one case in which the Finnish partner conducted an open recruitment, and eventually no employees from the Chinese partner were selected. This caused tension between the Finnish and Chinese partners. A Finnish partner who held a majority share could possess greater power in staffing issues, and the terms could be altered to favour the Finnish partner.

The use of personal relationships in hiring was common and an important means of recruitment when operations began. In a number of Finnish companies, the general manager, normally a Finn who was responsible for establishing the company, recruited as the first Chinese manager someone who had been his subordinate in the previous company in China. Then a few more people were hired through the recommendation of this Chinese manager's friends or acquaintances. The management team was then set up. The reason for resorting to personal relationships was that Finnish managers had few other options.

From the 2000s onwards, recruitment channels became more diversified. The internet became the most widely used means for recruiting office staff and professionals. The case companies reported using several popular nationwide recruitment portals, such as www.51job. com (qiancheng wuyou), www.chinahr.com (zhonghua yingcai) and www.zhaopin.com (zhilian zhaopin). Some companies also used the job portals for the economic zones in which the companies were located 
or which were nearby, an example being www.siphrd.com (Suzhou Industrial Park Human Resource Development). Recruitment websites could also be used by the companies to promote their image. A few of them had their name and logo placed on certain recruitment websites to promote themselves as attractive employers. The widely spread use of the internet as a recruitment channel has increased the openness and transparency of the labour market. The availability of human resources can be easily identified through the internet's assistance, and it is a very effective intermediary between potential job candidates and companies.

Recruiting via headhunters is another new method in China, and it has been developing very fast in recent years. As reported by some case companies, the primary reason for using headhunting companies was to identify suitable candidates for high-level managerial roles, as well as specialists and some key positions that could not be found on the open labour market. For example, one company recruited a quality manager via a headhunter: 'Quality manager is a such important position that we could not just recruit an unknown person from the market' (Interview with a Finnish managing director in China, 2 March 2010). In some cases, headhunters were used to assess candidates and check their backgrounds, and even to poach potential candidates. The use of headhunting services has become increasingly common, largely because of the challenge in finding suitable candidates because of the shortage of talent. Most of the case companies used headhunting services to a varying extent. With the increasing use of headhunting and the rapid spread of the internet, the reliance on personal relationships has decreased to a large extent.

The direct intake of fresh graduates from universities was used by some case companies. Recruitment was often targeted to students in certain universities that offered degree programmes closely related to the professional expertise needed by the company, for example in engineering. However, only large Finnish companies could afford such a practice, because they needed a relatively large number of such new graduates and had the resources to take this route.

Other recruiting channels included job fairs and labour centres. There are specialized job fairs for fresh university graduates (yingjieshen zhaopinhui). Job fairs were mostly used for recruiting new graduates, while hiring operational workers was mainly via local labour centres. However, internet portals for recruiting workers have begun to emerge in very recent years. 
Although foreign companies have enjoyed freedom in staffing since early and mid-1990s, challenge of recruiting suitable employees has not lessened. The reason is the increasing shortage of talent in the labour market throughout the mid-1990s to the 2010s. Extensive use of the internet, use of headhunters and direct intake from universities and colleges were the measures used to tackle this challenge. For instance, one company commented, 'Our purpose is to get the maximum number of applicants via the internet from whom we can select the best ones' (Interview with a Finnish R\&D Director in China, 23 September 2008). Quite often, there were very few candidates who possessed professional knowledge and experience as well as good English skills.

\section{Reward}

The Labour Law not only officially dismantled life employment but also revoked the egalitarian and seniority-based pay system. The case companies reported consistently that they could freely decide the wage level and wage structure, and that there was no authority intervention into reward issues if the rules regarding minimum wage and overtime pay were followed. As the minimum wage standard was considerably lower than that of Finland, this regulation was not perceived to be a pressure. Labour supply and demand in the market were the key source of influence on company wage levels. The companies reported that they had to follow the market price of salaries constantly and adjust their wage levels accordingly. Maintaining a competitive salary level is key to reducing employee turnover and keeping the workforce stable. The consumer price index (CPI) published by the Chinese government was regarded as the minimum level for a general annual wage increase. For instance, the CPI was 5 per cent in 2008. Office staff and managers had higher increases in salary, between 10 and 20 per cent annually. For key personnel this could be even higher. Salary is not only linked to market price but also to performance.

The larger companies were able to identify the market salary level accurately by utilizing the services of multinational consulting companies, such as Mercer and Hewitt. They could obtain classified statistical information on salary by, for example, industrial sector, geographic area and even named competitors. In some companies it was a global human resources (HR) policy to use a fixed consulting company (often a global company) to provide salary information and to follow its grading system, an example being Mercer's international position evaluation (IPE), the most popular salary grading system. The smaller 
companies relied on public sources, such as wage statistics published by local governments and the experience of job candidates, who were asked to provide the salaries of their current jobs on their application form or during an interview.

In defining individual wage and salary levels, education, professional qualification, work experience, foreign language skill (normally English) and level of job demand were all important factors. There was clear evidence of a differentiated salary policy in the companies. This was competence-based and also served as a mechanism to motivate employees, as one Finnish manager commented: 'Those with more skills, more experience, of course, should have higher salary than new beginners with less experience and so on. Hierarchy is quite important to maintain' (Interview with a Finnish general manager in China, 7 January 2009). The differentiation in reward was also geared to serve company strategy. For instance, a market expansion strategy prompted companies to make considerable efforts in sales and customer services, which were called the 'front line'. Sales personnel had a different bonus scheme from other employees. Their bonus was directly linked to sales results and could be much more than the average. 'In our company the [sales] bonus part is quite big, so our sales people have the highest earning in the company, much higher than others' (Interview with a Finnish general manager in China, 11 August 2008). The possible side effect of this was that engineers hopped to sales jobs, thus worsening the shortage of technical professionals.

Some of the case companies had special reward arrangements for high potential. For example, one company had a savings plan for highly desired employees, who received a certain percentage of extra pay if they had worked for three years in the company. In actual fact, this was a retention plan that aimed to tackle the high turnover of key personnel. Reward together with recruitment and retention were regarded as the top three priorities in HRM. One general manager noted, 'People always talk about a few things: how you retain employees, how you treat employees and how you train employees that they won't run away' (Interview with a Chinese general manager, 17 August 2008).

In general, it was common procedure to implement differentiated pay and bonus in the case companies. In addition, there were other bonuses, such as attendance bonus, Chinese New Year bonus and a 13th month salary. This last was paid to all who had worked for the company for a full calendar year. Not all the companies had many bonuses. One interviewee reported that the company had only a year-end bonus based on 
company results and did not pay a 13th month salary. Another company had just begun to implement a bonus policy although it had operated in China for several years. In fact, there was only a small number of companies that had a variety of bonuses.

\section{Performance-based Pay}

A performance-based bonus system was widely applied in the case companies. Workers' bonuses were locally based. They were linked to key performance indicators (KPI) and evaluated monthly, quarterly or biannually. 'There is [a bonus] in Finland, but it's not based on the factors. It's based on sales turnover and profit. It is totally different. We would like to have a system linked more directly to the performance in China' (Interview with a Finnish general manager in China, 19September 2008). The maximum bonus was normally around 20 per cent of the wage, and the actual figure paid depended on the performance evaluation result. The bonus for managers (usually top managers) was linked to the financial results of the company. When yearly targets were met, managers could receive a bonus according to the preset percentage in the annual budget plan, which was agreed with the parent company. In the larger companies there was often a global bonus scheme covering managers at higher levels. Normally it was partly linked to the corporate result and partly to the Chinese subsidiary result. The maximum percentage varied from 10 per cent to 30 per cent of the annual salary.

Very differently from the situation in the early reform period, when egalitarianism was the mainstream thinking, case companies reported that employees with good performance wanted to be recognized with higher financial reward and distinguished from those who had performed more poorly. An HR manager noted, 'Performance appraisal must be linked to financial reward and benefits; otherwise it does not make much sense. Furthermore, it should be linked to training opportunities and employee personal development' (Interview with a Chinese HR manager, 18 September 2008). Indeed, many case companies linked bonuses either to individual or to both individual and group performance. Performance appraisal was also attractive to employees, because they saw the developmental discussion as a chance to gain access to training and thus advance their career. 


\section{Conclusion: Institutions as Constraints and Enablers}

This study has examined the changes in the HRM practices of foreign companies alongside the economic reform that has taken place in China since 1978. It demonstrates that HRM is tightly embedded in the institutional environment where multinational companies operate. In the early period of reform, although labour regulations for foreign enterprises allowed them to enjoy, to some extent, autonomy in employment practices, for example hiring people and defining wages, at the same time they were restricted in hiring (e.g. locally based hiring and approval of labour contract) and setting wage levels. This was due to the overall restrictive formal framework, which was still largely maintained by the centrally controlled labour administration. In addition, informal institutions such as egalitarian thinking among Chinese employees and managers, authority intervention into wage issues and the retaining of personnel files by SOEs acted as constraints on foreign enterprises to conduct desirable people management practices. These norms and work culture (informal institutions) were the legacies of the formal rule of China's socialist planned economy (North 1990).

In the later reform period, the relaxation of labour market institutions not only permitted but also encouraged foreign enterprises to pursue their preferred HRM practices. For instance, evidence from the Finnish companies shows that they are now able to conduct open recruitment by using various channels and applying Western selection procedures and assessment tools, as well as widely exercising differentiated reward policies based on performance, job demand and responsibility, experience and skills. Some other studies (e.g. Sanyal and Guvenli 2000; Walsh and Zhu 2007) show similar findings. The formal institution of the labour market in China much resembles liberal market economies (Hall and Soskice 2001), where general skills are formed primarily outside firms in educational institutions and are highly portable across companies.

Although the formal institutional environment in the later reform period enables foreign companies to carry out desired HRM practices, the need for local adaption has not reduced. Legacies of the centrally planned economy, such as an egalitarian philosophy, that prevailed in the early reform period have dramatically decreased. Yet individualist values and a new informal institution, characterized by emphasizing material reward and career progression, have emerged and become prevalent, especially among younger generations who were born during the age of reform, namely in the 1980s, 1990s and 2000s. The Chi- 
nese labels of 'post-70s' (qilinghou), 'post-80s' (balinghou), 'post-90s' (jiulinghou) and 'post-00s' (linglinghou) vividly capture the fast pace of generational change: a new generation emerges every decade. The 1980s and 1990s generations represent young people who are highly mobile and seek individualist achievement, and at the same time value a good work environment. Foreign companies have to adapt their HRM practices to meet the demand of new cultural norms. In addition, the fast-changing environment in legislation, heterogeneous socio-economic development across the country and the highly competitive labour market all add complexity for foreign companies involved in people management in China.

WEI LU is a post-doctoral researcher at Aalto University School of Business. Her research interests focus on China, including the internationalization strategies of Finnish companies in China, economic reform and institutional transition in China, adaptation of HRM practices in multinational corporations (MNCs), Chinese Finnish communication and organizational commitment of Chinese employees. Email: wei.lu@aalto.fi

\section{NOTES}

1 The terms 'socialist planned economy' and 'social market economy' (used later) are adopted from the Chinese government's official terminologies.

2 Personal interviews were conducted between 2005 and 2010 with 61 Finnish companies in various sectors (e.g. machinery, equipment, metal, paper, engineering and electronics) that were operating in China. The interviewees included managers and business executives of these companies, and they were Finnish and Chinese nationals.

3 Danwei have played a pervasive role in China's urban society, binding their employees to them in a culture of dependence. With their many functions, they are not just a workplace but a social institution. They satisfy the basic needs of their employees and their dependants, represent their interests, define their social status, accord them various rights, and control and influence their behaviour (Knight and Song 2005: 27).

4 It was reported that China's coal industry laid off 187,000 workers in the first half of 1993 (South China Morning Post International Weekly, 9-10 October 1993).

\section{REFERENCES}

Björkman, Ingmar, Adam Smale, Jennie Sumelius, Vesa Suutari and Yuan Lu 2008. 'Changes in Institutional Context and MNC Operations in China: Subsidiary HRM Practices in 1996' versus 2006, International Business Review 17: 146-158. https:/ / doi. org/10.1016/j.ibusrev.2008.02.001 
Wei Lu

Brødsgaard, Kjeld Erik, and Koen Rutten 2017. From Accelerated Accumulation to Socialist Market Economy in China. Leiden and Boston: Brill. https://doi.org/10.1163/9789 004330092

Chai, Joseph 1998. China: Transition to a Market Economy. Oxford: Clarendon Press.

Chen, Kang 1995. The Chinese Economy in Transition: Micro Changes and Macro Implications. Singapore: Singapore University Press.

Child, John 1994. Management in China during the Age of Reform. Cambridge: Cambridge University Press.

China net 2003. 'Zhongguo qiye shichanghua gaige huigu' (Review of Marketization Reform of Chinese Enterprises). http:/ / www.china.com.cn/chinese/zhuanti/306653. htm. Accessed 19 January 2008.

CPC 1984. 'Zhonggong zhongyang guanyu jingji tizhi gaige de jueding' (the Decision on Economic Reform by the Third Plenary Session of the Twelfth Central Committee of the CPC), October 20. http:/ / cpc.people.com.cn/GB/64162/134902/8092122. html. Accessed 7 December 2018.

Gallagher, Mary 2004. "'Time is Money, Efficiency is Life": The Transformation of Labor Relations in China'. Studies in Comparative International Development 39 (2): 11-44. https://doi.org/10.1007/BF02686276

Goodall, Keith and Malcolm Warner 1997. 'Human Resources in Sino-Foreign Joint Ventures: Selected Case Studies in Shanghai, compared with Beijing. The International Journal of Human Resource Management 8 (5): 569-594. https:/ / doi.org/10.1080/09 5851997341397

Greene, Joel 1991. 'FIEs face New Labor Obstacles'. China Business Review 18 (1): 8-12.

Hall, Peter and David Soskice 2001. Varieties of Capitalism: The Institutional Foundations of Comparative Advantage. Oxford: Oxford University Press. https://doi.org/10.10 93/0199247757.001.0001

Kettunen, Erja, Jyri Lintunen, Wei Lu and Riitta Kosonen 2008. Suomalaisyritysten strategiat Kiinan muuttuvassa toimintaympäristössä (Strategies of Finnish Companies in the Changing Business Environment of China). Helsinki School of Economics Publications B-98.

Knight, John, and Lina Song 2005. Towards a Labour Market in China. Oxford: Oxford University Press. https://doi.org/10.1093/0199245274.001.0001

Laaksonen, Oiva 1988. Management in China During and after Mao in Enterprises, Government, and Party. Berlin and New York: Walter de Gruyter.

Lu, Wei 2009. 'The Effects of Legal Institution on MNC Subsidiaries' HRM Practices in China'. In Wesley Scroggins, Claudia Gomez, Philip Benson, Richard Oliver and Michael Turner (eds.) Celebrate the Tapestry: Diversity in the Modern Global Organization. Proceedings of the 10th International Human Resource Conference, Santa Fe, NM, USA, 21-24 June 2009.

Lu, Wei 2014. Localization of Human Resource Management Practices in China: A Qualitative Comparative Analysis Approach. Ph dissertation, Aalto University.

Nelson, James, and John Reeder 1985, Labour Relations in China, California Management Review 27 (4): 13-32. https:/ / doi.org/10.2307/41165153

North, Douglass 1990. Institutions, Institutional Change, and Economic Performance. Cambridge, MA: Harvard University Press. https://doi.org/10.1017/ CBO9780511808678

NPC 1986. 'Zhonghua renmin gongheguo qiye pochanfa (shixing)' (Provisional Law on Enterprise Bankruptcy of People's Republic of China), 2 December. http:/ / www.npc. gov.cn/wxzl/wxzl/2000-12/06/content_4475.htm. Accessed 7 December 2018. 
NPC 1993. 'Zhonghua renmin gongheguo gongsifa' (Company Law of People's Republic of China), 29 December. http://www.npc.gov.cn/wxzl/wxzl/2000-12/05/content_4608.htm. Accessed 7 December 2018.

NPC 1994. 'Zhonghua renmin gongheguo laodongfa' (Labour Law of People's Republic of China), 5 July. http://www.npc.gov.cn/wxzl/gongbao/2000-12/05/content_ 5004622.htm. Accessed 7 December 2018.

NPC 1999. 'Zhonghua renmin gongheguo xianfa xiuzhengan' (Constitution Amendment of People's Republic of China), 15 March. http:/ / www.npc.gov.cn/wxzl/wxzl/200012/10/content_7075.htm. Accessed 7 December 2018.

NPC 2004. 'Zhonghua renmin gongheguo xianfa' (Constitution of People's Republic of China), 14 March. http://www.npc.gov.cn/npc/zt/qt/gjxfz/2014-12/03/content_1888091.htm. Accessed 7 December 2018.

NPC 2007. 'Zhonghua renmin gongheguo laodong hetongfa' (Labour Contract Law of People's Republic of China, 29 June. http:/ / www.npc.gov.cn/wxzl/gongbao/201304/15/content_1811058.htm. Accessed 7 December 2018.

OECD (Organisation for Economic Co-operation and Development) 2005. Economic Survey of China. Paris: OECD Publishing.

Peng, Mike 2000. Business Strategies in Transition Economies. Thousand Oaks, CA, London and New Delhi: Sage Publications.

Peng, Mike and Peggy Heath 1996. 'The Growth of the Firm in Planned Economies in Transition: Institutions, Organizations and Strategic Choices'. Academy of Management Review 21 (2): 2492-2528. https:// doi.org/10.5465/amr.1996.9605060220

People net 10 January 2009. 'Sanshi nian guoqi gaige lichen huigu' (Retrospect of the 30-year Reform of State-owned Enterprises). http://theory.people.com.cn/ GB/49154/49155/8655145.html. Accessed 14 April 2012.

Report on Foreign Investment in China 2018. MOFCOM. http:/ / images.mofcom.gov. cn/wzs/201810/20181009090547996.pdf. Accessed 4 December 2018.

Sanyal, Rajib and Turgut Guvenli 2000. 'Human Resource Issues in American Firms in China'. Journal of Asia-Pacific Business 2 (4): 59-82. https://doi.org/10.1300/ J098v02n04_05

State Council 1980. 'Zhonghua renmin gongheguo zhongwai hezi jingying qiye laodong guanli guiding' (Provisions on Labour Management in Chinese-Foreign Equity Joint Ventures of People's Republic of China), 26 July. http://www.law-lib.com/law/ law_view.asp?id=2120. Accessed 7 December 2018.

State Council 1984. 'Guanyu jinyibu kuoda guoying gongye qiye zizhuquan de zanxin guiding' (Provisional Regulations on Further Expanding the Autonomy of StateOwned Industrial Enterprises), 10 May. http:/ /cpc.people.com.cn/GB/64162/641 65/79703/79788/5620505.html. Accessed 7 December 2018.

State Council 1986. 'Guoying qiye shixing laodong hetongzhi zanxing guiding' (Provisional Regulations on the Use of Labour Contract in State Owned Enterprises), 12 July. http://www.wsic.ac.cn/policyandregulation/47921.htm. Accessed 4 December 2018.

State Council 1988. 'Guowuyuan bangongting guanyu zhuanbi laodongbu renshibu guanyu jinyibu luoshi waishang touzi qiye yongren zizhuquan yijian de tongzhi' (Circular of the General Office of the State Council on the Approval and Transmission of the Proposals Submitted by the Ministry of Labour and the Ministry of Personnel Concerning Further Implementation of the Policy of Granting Decision-making Power to Enterprises with Foreign Investment for the Employment of Working Personnel), 5 May. http://www.fdi.gov.cn/1800000121_39_3303_0_7.html. Accessed 4 December 2018. 
Wei Lu

Tsang, Eric 1994. 'Human Resource Management Problems in Sino-Foreign Joint Ventures'. International Journal of Manpower 15 (9-10): 4-21. https://doi.org/10.11 08/01437729410074173

Tung, Rosalie 1982. 'Selection and Training Procedures of U.S., European, and Japanese Multinationals'. California Management Review 259 (1): 57-71. https:/ / doi. org/10.2307/41164993

UNCTAD 2018. World Investment Report 2018. New York and Geneva: United Nations. https://unctad.org/en/PublicationsLibrary/wir2018_en.pdf. Accessed 4 December 2018.

Verburg, Robert 1996. 'Developing HRM in Foreign-Chinese Joint Ventures'. European Management Journal 14 (5): 518-525. https:/ / doi.org/10.1016/0263-2373(96)00046-1

Walder, Andrew 1989. 'Factory and Worker in an Era of Reform'. China Quarterly 118: 242-264. https://doi.org/10.1017/S030574100001780X

Walsh, Janet and Ying Zhu 2007. 'Local Complexities and Global Uncertainties: A Study of Foreign Ownership and Human Resource Management in China'. International Journal of Human Resource Management 18 (2): 249-267. https:/ / doi.org/10.1080/0 9585190601102430

Warner, Malcolm 1995. The Management of Human Resource in Chinese Industry. London: Macmillan and New York: St Martin's Press. https://doi.org/10.1057/978023038 0066

Wu, Victoria 2006. 'Labor Relations in Focus: the PRC Government's Efforts to Better Protect Workers' Rights Spring from Worries About China's Social Stability'. China Business Review. November-December: 40-43.

Yung, Anna and Ng Sek Hong 2008. 'A New Brand of the Individual Labour Contract under Market Socialism: Case Studies in the Shenzhen Special Economic Zone of China'. International Journal of Employment Studies 16 (1): 1-37.

Yusuf, Shahid, Kaoru Nabeshima and Dwight Perkins 2006. Under New Ownership: Privatizing China's State Owned Enterprises. New York: Stanford University Press and the World Bank.

Zhu, Cherrie and Peter Dowling 2000. 'Managing People During Economic Transition: The Development of HR Practices in China'. Asia Pacific Journal of Human Resources 38 (2): 84-106. https:/ / doi.org/10.1177/103841110003800207 